\title{
Eliciting the Financial Challenges Facing Emerging Contractors in Developing Countries Using the Critical Incident Technique: A Case of South African Construction Industry
}

\author{
Hove George \\ UNISA School of Business Leadership, Cnr Janadel \& Alexandra Avenue, Midrand, Gauteng, \\ South Africa \\ E-mail: 71759956@mylife.unisa.ac.za
}

Received: Oct. 6, 2016 Accepted: Oct. 25, 2016 Published: Nov. 9, 2016

doi:10.5296/bmh.v4i2.10289

URL: http://dx.doi.org/10.5296/bmh.v4i2.10289

\begin{abstract}
The purpose of this paper was to determine the financial critical incidents that are encountered by emerging contractors in the construction industry in Gauteng, South Africa. The methodology of assessment was based on critical incident technique, a qualitative method which has been considered reliable in tourism and hospitality studies. An interview guide which was evaluated in terms of reliability and validity was used to collect critical incidents from the respondents. Based on the interviews conducted, the respondents highlighted twenty eight financial critical incidents perceived to have an impact or impacts on Emerging Contractors' performance. The incidents identified were the inability of Emerging Contractors to properly manage cash flow, poor budgetary planning and cash flow, poor financial decision making and lack of collateral. In order to improve Emerging Contractors' performance, executives are required to plan construction projects in order to guide their execution and control. The limitation of the study was that the perceptions drawn were extracted from 12 respondents who represented emerging contractors in Gauteng Province. Therefore, the results of the study cannot be generalised to the entire South Africa construction industry, however they can be used as part of the solution towards Emerging Contractors' performance.
\end{abstract}

Keywords: Critical incident, Construction industry, Emerging contractor, Gauteng, South Africa 


\section{Introduction and Background}

In South Africa (SA), the construction industry development board (CIDB) Act defines emerging contractor (ECs) as small business which is owned (at least 50\%), managed and controlled by previously disadvantaged persons and which is overcoming business impediments arising from the legacy of apartheid. This refers to small-scale construction enterprises in CIDB graded 2-5 (CIDB 2010). ECs have a significant role towards the economic growth and development of the country (Greyling, 2012; Buys \& Daluxolo, 2012; Twala \& Mvubu, 2009). They are essential vehicles which attend to challenges of job creation, increase social development levels and help balance the development inequalities. Although policy makers and researchers have been talking about developing ECs in the construction sector for more than twenty years, the performance of ECs has remained low in terms of growth and profitability. Considering the great attention gained from researchers (Emuze, 2011; Baloyi \& Bekker, 2011; Booyens, 2011; Odeyinka \& Kaka, 2005; CIDB, 2013; Ofori, 2009) over the years, the unemployment, poverty and other challenges facing the SA economy could have been dealt with by now. From a managerial perspective, availability of resources seem to play a significant role in the performance of ECs. Using this argument as a starting point, this paper aims to give a contribution to ECs performance by identifying salient financial factors that hinder ECs performance. On the basis of reviewed literature and investigation using the critical incident technique (CIT), this paper addresses the following research questions:

- What are the most common financial critical incidents that are faced by ECs in the SA construction industry?

- What are the possible ways of resolving the incidents or mitigating their impact?

- What are the resulting implications for the performance of ECs?

\section{Research Design and Methodology}

This research took a qualitative approach and was conducted using the critical incident technique (CIT) in the Gauteng Province. Despite being the oldest method of research technique, relatively little is known about CIT in the construction industry. There are very few studies if any that have employed CIT technique to gather information associated with financial challenges within the construction industry. This lack of knowledge could be a result of a number of factors ranging from invisible nature of the technique and the fact that incidents are regarded as insignificant, hence researchers tend to undermine their relevance. However, incidents are a useful approach to identify performance improvement needs and their sources (Marrelli, 2005). An analysis of incidents provides a rich, in-depth perspective of the situation in an organisation that is usually not apparent through more quantitative methods of data collection.

\subsection{Target Population and Sampling Strategy}

The research population was limited to the ECs in Gauteng, the most prosperous province in South Africa. Purposive sampling method was used because the researcher wanted to 
interview knowledgeable and experienced respondents from the selected ECs. The method is a deliberate choice of a respondent as to who to include in the study based on their ability to provide necessary data (Parahoo, 1997). This is in line with Patton (2002), who stated that purposive sampling technique does not need underlying theories or a set number of respondents but the researcher decides what needs to be known and sets out to find people or organisation who can and are willing to provide the information by virtue of knowledge and experience. There were 89 ECs deemed to have knowledgeable respondents about the critical financial incidents encountered by ECs. These ECs formed the population for the study and within that, only 12 ECs were willing to provide information for the study giving a response rate of $13 \%$. Since the study was of qualitative nature, the response rate was acceptable. The information was provided by selected knowledgeable executives as representatives of the 12 ECs. The executives were builders, carpenters, steel fixers and general contractors who could provide meaningful information and answers to the research questions.

\subsection{Data Collection Instrument}

A review of literature (e.g., Keaveney 1995; Serenko \& Stach 2009; Bitner et al., 1994) identified critical incidents scales which had been tested and used in marketing, customer satisfaction and tourism environments. Based on these scales and inputs from experts, an in-depth interview guide was developed. The interview guide items were developed in a way that the instrument would suit the South African environment.

\subsection{Pilot Study}

According to Holloway \& Wheeler (2002), pilot studies are not usually used in qualitative studies however in this study interviews were conducted with two respondents as a pre-exercise to get used to the type of data collection. The three respondents had met the selection criteria and were industry experts. Thus, the pilot study helped in the refinement of data collection instrument in terms of content and procedures, development of relevant lines of questioning and improvement of field procedures like making appointments and notes taking.

\section{Profile of the Respondents and Analysis of the Findings}

The profile of the respondents (A-L) are summarised in Table 1 (below) while table 2 summarises the critical incidents that emerged from interviews conducted with the respondents. In table 2, Column 1 represents the common financial critical incidents that were encountered by respective ECs as reported by the executives while columns 2 to 13 represent the individual responses.

\subsection{Frequency of Occurrence}

There were twenty eight critical incidents extracted from the completed interview guide. The distribution of the identified incidents showed that late payments, poor cash flow management, poor budgetary planning and controls, corruption and bribery on sites, poor financial decision making, lack of collateral and assets were the most frequent incidents encountered by ECs occupying the top group (ranging from 83\% to 100\%). In the middle of 


\section{Macrothink}

the grouping were incidents related to delays on sites, non-payment of employees, poor record keeping, use of personal and family resources, disruption of working activities due to power cuts and failure to inadequate working capital (ranging from 50\% to 75\%). The incidents that had the least ranking were payment of employees for medical aid, use of business money for personal and family needs, part payment of due accounts and use of non-financial sources to raise capital (from $8 \%$ to $42 \%$ ). All the respondents reported an average of seventeen incidents (table 2 refers) that had been encountered by their respective ECs and this demonstrates the extent to which critical incidents have on businesses.

Table 1. Profile of respondents

\begin{tabular}{|c|c|c|c|c|c|c|c|c|c|c|c|c|}
\hline \multicolumn{13}{|c|}{ Responses received } \\
\hline Study Area & $A$ & B & c & D & E & $F$ & G & н & I & $\mathbf{J}$ & к & L \\
\hline Gender & Female & Male & Male & Male & Male & Male & Male & Female & Male & Male & Male & Male \\
\hline Age Group & 58 years & 61 years & 28 years & 46 years & 38 years & 34 years & 42 years & 54 years & 33 years & 38 years & 45 years & 29 years \\
\hline Ethnic group & Black & Black & Black & White & Black & Black & Black & Black & Black & Black & Black & Black \\
\hline Disability & None & None & None & None & None & None & None & None & None & None & None & None \\
\hline Qualification & No matric & No matric & Matric & Matric & $\begin{array}{l}\text { Teaching } \\
\text { Diploma }\end{array}$ & No matric & Matric & Matric & No matric & $\begin{array}{l}\text { Teaching } \\
\text { Diploma }\end{array}$ & Matric & Matric \\
\hline Profession & Builder & Builder & Reinforcing & $\begin{array}{l}\text { Builder/ } \\
\text { Reinforcing }\end{array}$ & $\begin{array}{l}\text { General } \\
\text { Contract }\end{array}$ & $\begin{array}{l}\text { Builder/' } \\
\text { Reinforcing }\end{array}$ & $\begin{array}{l}\text { General } \\
\text { Contract }\end{array}$ & Carpenter & $\begin{array}{l}\text { Builder/ } \\
\text { Reinforcing }\end{array}$ & Reinforcing & Builder & $\begin{array}{l}\text { Builder / } \\
\text { Reinforcing }\end{array}$ \\
\hline Functional role & CEO & Owner & $\begin{array}{l}\text { Contract } \\
\text { Manager }\end{array}$ & Owner & $\begin{array}{l}\text { Managing } \\
\text { Director }\end{array}$ & Owner & CEO & $\begin{array}{l}\text { Managing } \\
\text { Director }\end{array}$ & Owner & $\begin{array}{l}\text { Managing } \\
\text { Director }\end{array}$ & $\begin{array}{l}\text { Contract } \\
\text { Manager }\end{array}$ & Owner \\
\hline Province & Gauteng & Gauteng & Gauteng & Gauteng & Gauteng & Gauteng & Gauteng & Gauteng & Gauteng & Gauteng & Gauteng & Gauteng \\
\hline No. of Years & 2 years & 2 years & 3 years & 1 years & 3 years & 3 years & 3 years & 4 years & 2 years & 4 years & 3 years & 2 years \\
\hline CIDB Grading & Grade 2 & Grade 2 & Grade 2 & Grade 2 & Grade 2 & Grade 2 & Grade 2 & Grade 2 & Grade 2 & Grade 2 & Grade 2 & Grade 2 \\
\hline $\begin{array}{l}\text { Size } \\
\text { (employees }\end{array}$ & 35 & 47 & 17 & 54 & 15 & 36 & 42 & 35 & 24 & 33 & 37 & 46 \\
\hline $\begin{array}{l}\text { Business } \\
\text { Profile }\end{array}$ & $\begin{array}{l}\text { Male / } \\
\text { Female }\end{array}$ & Male & Male & Male & Malc & Male & Male & Male & Male & Male & Male & Male \\
\hline $\begin{array}{l}\text { Service } \\
\text { provided }\end{array}$ & CE & GB & $\mathrm{CE} \& \mathrm{~GB}$ & $\mathrm{CE} \& \mathrm{~GB}$ & $\mathrm{CE} \& \mathrm{~GB}$ & GB & GB & $\mathrm{CE} \& \mathrm{~GB}$ & GB & GB & $\mathrm{CE} \& \mathrm{~GB}$ & $\mathrm{CE} \& \mathrm{~GB}$ \\
\hline $\begin{array}{l}\text { Construction } \\
\text { Projects }\end{array}$ & $\begin{array}{l}\text { Govi/ } \\
\text { Private }\end{array}$ & Govt/Private & $\begin{array}{l}\text { Govi/ } \\
\text { Private }\end{array}$ & Gov/Private & Gov/ / Private & Govt/Private & Gov/ / Private & Govt/Private & Govt/Private & $\begin{array}{l}\text { Govt/ } \\
\text { Private }\end{array}$ & $\begin{array}{l}\text { Govt/ } \\
\text { Private }\end{array}$ & Govt/Private \\
\hline
\end{tabular}

Note. GB-General Building, CE-Civil Engineering, CEO-Chief Executive Officer, Gvt-Government. 


\section{Ml Macrothink}

Table 2. Summarised results on finance

\begin{tabular}{|c|c|c|c|c|c|c|c|c|c|c|c|c|c|}
\hline Financial Critical Incident Identified & $A$ & B & $\mathrm{C}$ & D & $\bar{E}$ & $F$ & G & H & 1 & $\mathrm{~J}$ & K & L & Overall total of Frequencies \\
\hline Late payment of claims by main contractor & $x$ & $\mathrm{x}$ & $\mathrm{x}$ & $\mathrm{x}$ & $x$ & $\mathrm{x}$ & $\mathrm{x}$ & $\mathrm{x}$ & $x$ & $\mathrm{x}$ & $\mathrm{x}$ & $\mathrm{x}$ & 12 \\
\hline Inability to properly manage cash flow & $\mathrm{x}$ & $\mathrm{x}$ & $\mathrm{x}$ & $\mathrm{x}$ & $\mathrm{x}$ & $\mathrm{x}$ & $\mathrm{x}$ & $\mathrm{x}$ & $x$ & $\mathrm{x}$ & $\mathrm{x}$ & $\mathrm{x}$ & 12 \\
\hline Poor budgetary planning and controls & $\mathrm{x}$ & $x$ & $x$ & $x$ & $x$ & $\mathrm{x}$ & $\mathrm{x}$ & $\mathrm{x}$ & $\mathrm{x}$ & $\mathrm{x}$ & $x$ & $\mathrm{x}$ & 12 \\
\hline Corruption and bribery on site & $\mathrm{x}$ & $\mathrm{x}$ & $\mathrm{x}$ & $\mathrm{x}$ & $\mathrm{x}$ & & $\mathrm{x}$ & $\mathrm{x}$ & $x$ & $x$ & $\mathrm{x}$ & $\mathrm{x}$ & 11 \\
\hline Poor financial decision making & $\mathrm{x}$ & $\mathrm{x}$ & $\mathrm{x}$ & $\mathrm{x}$ & $x$ & $x$ & $\mathrm{x}$ & $\mathrm{x}$ & & $\mathrm{x}$ & $\mathrm{x}$ & $\mathrm{x}$ & 11 \\
\hline Lack of collateral and assets required by the bank & $\mathrm{x}$ & $\mathrm{x}$ & $\mathrm{x}$ & & $x$ & $\mathrm{x}$ & $\mathrm{x}$ & $\mathrm{x}$ & $x$ & & $\mathrm{x}$ & $\mathrm{x}$ & 10 \\
\hline Poor contract interpretation & $\mathrm{x}$ & & $\mathrm{x}$ & $\mathrm{x}$ & $x$ & $\mathrm{x}$ & $\mathrm{x}$ & $\mathrm{x}$ & & $\mathrm{x}$ & $\mathrm{x}$ & $\mathrm{x}$ & 10 \\
\hline Lack of awareness of legal rights & $\mathrm{x}$ & $\mathrm{x}$ & & $x$ & $x$ & $x$ & $x$ & $x$ & $x$ & & $\mathrm{x}$ & $x$ & 10 \\
\hline Inadequate working capital & & $\mathrm{x}$ & $\mathrm{x}$ & $\mathrm{x}$ & & $\mathrm{x}$ & $\mathrm{x}$ & $\mathrm{x}$ & & $\mathrm{x}$ & $\mathrm{x}$ & $\mathrm{x}$ & 9 \\
\hline High interest rates from financial institutions & $\mathrm{x}$ & $\mathrm{x}$ & $\mathrm{x}$ & & $\mathrm{x}$ & $\mathrm{x}$ & $\mathrm{x}$ & & $\mathrm{x}$ & $\mathrm{x}$ & & $\mathrm{x}$ & 9 \\
\hline Not given a site instruction to claim for extra work done & $\mathrm{x}$ & $\mathrm{x}$ & $\mathrm{x}$ & & $x$ & $x$ & $\mathrm{x}$ & & $\mathrm{x}$ & $\mathrm{x}$ & $\mathrm{x}$ & & 9 \\
\hline Cut price to secure contract due to high competition & $\mathrm{x}$ & $\mathrm{x}$ & & $\mathrm{x}$ & $x$ & & $\mathrm{x}$ & & $\mathrm{x}$ & & $\mathrm{x}$ & $\mathrm{x}$ & 8 \\
\hline Very small profit margin realised from the contract & $x$ & & $\mathrm{x}$ & $\mathrm{x}$ & & $\mathrm{x}$ & $\mathrm{x}$ & $\mathrm{x}$ & & $\mathrm{x}$ & & $\mathrm{x}$ & 8 \\
\hline Lost retention due to project abandonment and claims & & $\mathrm{x}$ & $\mathrm{x}$ & $\mathrm{x}$ & $x$ & & & $\mathrm{x}$ & $\mathrm{x}$ & $\mathrm{x}$ & $\mathrm{x}$ & & 8 \\
\hline Deduction of retention affected cash flow & $\mathrm{x}$ & $\mathrm{x}$ & & $\mathrm{x}$ & & $\mathrm{x}$ & $\mathrm{x}$ & $\mathrm{x}$ & & $\mathrm{x}$ & & $\mathrm{x}$ & 8 \\
\hline Disnuption of work due to power cuts & $x$ & & & $x$ & $\mathrm{x}$ & $\mathrm{x}$ & $x$ & & $\mathrm{x}$ & $\mathrm{x}$ & & & 7 \\
\hline Low productivity due to poor supervision & & $\mathrm{x}$ & $\mathrm{x}$ & & $\mathrm{x}$ & & & $\mathrm{x}$ & $\mathrm{x}$ & & $\mathrm{x}$ & $\mathrm{x}$ & 7 \\
\hline Failed to raise performance guarantee & $\mathrm{x}$ & & $\mathrm{x}$ & & & $\mathrm{x}$ & $\mathrm{x}$ & $\mathrm{x}$ & & $\mathrm{x}$ & $\mathrm{x}$ & & 7 \\
\hline Failed to pay employees & $\mathrm{x}$ & & & $\mathrm{x}$ & & $\mathrm{x}$ & & $\mathrm{x}$ & $\mathrm{x}$ & & $\mathrm{x}$ & $\mathrm{x}$ & 7 \\
\hline Delays on site due to main contractor problems & $\mathrm{x}$ & $\mathrm{x}$ & & & $x$ & $\mathrm{x}$ & & & $x$ & & $\mathrm{x}$ & & 6 \\
\hline No proper records kept to track on business transaction & & $x$ & & $\mathrm{x}$ & & $\mathrm{x}$ & $x$ & & $\mathrm{x}$ & & $\mathrm{x}$ & & 6 \\
\hline Stopped working waiting for payment & $\mathrm{x}$ & & $\mathrm{x}$ & & & $\mathrm{x}$ & $\mathrm{x}$ & & & $\mathrm{x}$ & & $\mathrm{x}$ & 6 \\
\hline Paid employees from own savings & $\mathrm{x}$ & $\mathrm{x}$ & & $\mathrm{x}$ & & & $\mathrm{x}$ & & $\mathrm{x}$ & & & & 5 \\
\hline Borrowed money from non-financial sources & & & $\mathrm{x}$ & & $\mathrm{x}$ & & & & $\mathrm{x}$ & & & $\mathrm{x}$ & 4 \\
\hline Got financial assistance from family and friends & $\mathrm{x}$ & & & & $\mathrm{x}$ & & $\mathrm{x}$ & & & & & & 3 \\
\hline Paid half of the amount to avoid stoppages & & & & $x$ & & & & $\mathrm{x}$ & & & & $x$ & 3 \\
\hline Used cash received for personal needs & & & $\mathrm{x}$ & & & & $\mathbf{x}$ & & & & & & 2 \\
\hline Paid employees to go for medicals, first aid training & & & & & & & & $\mathrm{x}$ & & & & & 1 \\
\hline Total Frequencies of critical incidents & 20 & 17 & 17 & 17 & 17 & 18 & 21 & 17 & 17 & 15 & 17 & 18 & \\
\hline
\end{tabular}

\subsection{Analysis of the Impact of the Identified Critical Financial Incidents on ECs' Performance}

The relative severity of the financial incidents encountered by ECs in Gauteng was analysed:

\subsubsection{On Late Payments of Completed Work}

All the respondents, reported incidents of late payments from contracting clients. This result shows that ECs are paid for completed work beyond the time stipulated in the conditions of contracts. The resultant of this incident is delays of building construction projects as the ECs would not have sufficient cash flow to run the project. This was confirmed by A, B, E, F, I and $\mathrm{K}$ who stopped working waiting for payment.

\subsubsection{On Lack of Collateral and Assets Required by the Bank}

Most of the respondents highlighted lack of collateral security in the form of assets as a challenge towards EC business performance. There were concerns raised by the respondents regarding access to finance from financial institutions. They indicated that banks are reluctant to deal with ECs due to poor credit rating and that they charged exorbitant interest rates. This shows that most of the ECs fail to raise capital through the formal institutions because of lack of collateral and assets. Instead, ECs borrow money from non-formal sources, family members and friends as reported by $\mathrm{C}, \mathrm{E}, \mathrm{I}$ and $\mathrm{L}$ in the analysis. As expected, informal sources of income are not sustainable and expensive to run a business. 


\subsubsection{On Inadequate Working Capital}

Inadequate working capital plays a negative role in the performance of ECs businesses as ECs enter into construction work without adequate capital. For example, Respondent E said: "the client wanted a performance guarantee which I couldn't raise". This demonstrates that ECs fail to secure tenders due to limited working capital. The study also found that executives use non-banking facilities as a source of finance to hire tools, equipment and machinery that included the Bulldozer, the Front-end Loader, Bomag Roller and the Excavators used for bulk excavation.

\subsubsection{Poor Cash Flow Management and Poor Recordkeeping}

The respondents felt that short of funds during construction of projects compromises business growth and profitability. All respondents confirmed late payment attributing to cash flow problems as respondents find themselves using own equity to pay wages and salaries. Incident of poor recordkeeping was highlighted by respondents B, D, F, G, I and K. Although respondent $\mathrm{F}$ received some payment from the client, the funds were used for personal use, resulting in failure to pay employees' wages and salaries. Similarly, respondent D had no systems to keep records such as construction drawings, bending schedules, invoices, orders and payment record because he lacked necessary skills. This result confirms the incident of budgetary planning and controls where all respondents demonstrated poor business controls.

\subsubsection{On Deduction of Retention}

The study found that payment of performance guarantees or deduction of retention is commonly practiced in the industry. Clients retain 5\% to 10\% (CIDB, 2013) of each progress payment until certified completion of the project, and this has a negative impact on cash flows of ECs. Respondent D worked for a large construction company and deductions of retention were made on the understanding that it would be paid out upon project completion. After a year, there were claims between the client and the main contractor which resulted in the project being abandoned and respondent $\mathrm{D}$ lost the cash that had been paid to the main client. Similarly, respondent $C$ reported misunderstandings with the main contractor that led to project abandonment and lost retention money accrued, while respondent $\mathrm{F}$ failed to recover retention money due to non-compliance with health and safety requirements.

\subsubsection{On Low Bidding Price / Unrealistic Tender price}

All Executives agreed that pricing a project too low affected the survival of the businesses and resulted in insufficient profits to the company. For example, respondent $\mathrm{C}$ reported: "The profit margin for this job (construction of a police station) was very small. The price that I accepted on that tender was very low due to competition and had to go for low prices in order to secure the job." This result suggest that the prices used by ECs to secure construction jobs are low to sustain business success, profits achieved are low if not negative and would not be sufficient to cover all business expenses. In any business operation, lower than expected profits are a major concern that should always be protected. This further demonstrates lack of experience and understanding of project costing among ECs executives and needs to be addressed if they are to make profits and grow. 


\subsubsection{On Site Instruction}

Most of the respondents highlighted non-payment of rework of defective project units as an impediment towards businesses profitability, especially when the problem was caused by the main contractor. The respondents (A, B, C, E, F, G, I, J and K) reported that site instructions were not easily accessible and could not make a claim for work done. For example, respondent $\mathrm{C}$ specified non-payment for processing reinforcing steel on site, but in spite of this employees were paid for extra work. However, in the construction industry, when such incident happens, the main contractor is required to issue a site instruction that would be used to make a claim. Such practices have a knock-on effect on ECs' performance as they are unable to recover such costs. Again, this demonstrates the long and bureaucratic processes experienced by ECs towards receiving payments.

\section{Ways of Resolving the Incidents}

The last question on the interview guide requested the respondents to provide their opinions on "how could the incident be handled differently?" This question gave the respondents the opportunity to provide ways that could be utilised to resolve the incidents. Their responses to this question were guided by lessons learnt and effective actions taken in previous encounters. The question was vital and important to solicit ways of resolving the incidents. Based on the respondents' inputs, table 3 (below) summarises possible ways of resolving the incidents.

Table 3. Possible ways of resolving the incidents

\begin{tabular}{|c|c|}
\hline Financial Critical Incident Identified & Possible ways of resolving the incidents \\
\hline Late payment of claims by main contractor & $\begin{array}{l}\text { A policy is required that enables ECs to be paid by clients once a certificate has been issued and should do away with the } \\
\text { culture of 'pay when paid'. }\end{array}$ \\
\hline Corruption and bribery on site & The government should create transparency openness on government tenders, cut red tapes in government departments. \\
\hline Lack of collateral and assets required by the bank & $\begin{array}{l}\text { There are two scenarios that emerged from discussions: that some ECs simply do not have any asset to offer to banks and } \\
\text { that some have assets that could not be accepted as collateral. The respondents agreed that government intervention is } \\
\text { required. }\end{array}$ \\
\hline Poor contract interpretation & $\begin{array}{l}\text { ECs should seek legal advice, get acquainted with the terms and conditions of the contract before engaging themselves into } \\
\text { the project. }\end{array}$ \\
\hline Lack of awareness of legal rights & $\begin{array}{l}\text { The Construction development Industry Development Board should create awareness on legal issues that affect ECs and } \\
\text { how to mitigate their impact. }\end{array}$ \\
\hline High interest rates from financial institutions & $\begin{array}{l}\text { ECs must charge prices high enough to cover costs that include interest rates and this is an essential practise for any } \\
\text { business to survive. }\end{array}$ \\
\hline $\begin{array}{l}\text { Not given a site instruction to claim for extra } \\
\text { work done }\end{array}$ & $\begin{array}{l}\text { ECs must not engage in extra work required by the client without a site instruction. The site instruction would pave way for } \\
\text { payment. }\end{array}$ \\
\hline $\begin{array}{l}\text { Cut price to secure contract due to high } \\
\text { competition }\end{array}$ & $\begin{array}{l}\text { Despite, high competition, ECs must charge competitive prices and provide clients with superior services such as on-time } \\
\text { delivery, regular communication, and technical advice. }\end{array}$ \\
\hline $\begin{array}{l}\text { Very small profit margin realised from the } \\
\text { contract }\end{array}$ & charge competitive prices and ensure costs are contained within appropriate levels. \\
\hline $\begin{array}{l}\text { Lost retention due to project abandonment and } \\
\text { claims }\end{array}$ & $\begin{array}{l}\text { ECs must always check on warning signs from the client for example rumours from suppliers and subcontractors, } \\
\text { difficulties by client in securing material and labour and unjustified reduction in productivity. ECs take these warnings } \\
\text { seriously and position themselves appropriately. }\end{array}$ \\
\hline Deduction of retention affected cash flow & A policy is required where retention is done away with, however, ECs are expected to produce projects of high standards \\
\hline Disruption of work due to power cuts & Government intervention through the provision of appropriate infrastructure such as electricity. \\
\hline Low productivity due to poor supervision & ECs to train employees and hire qualified and competent workforce. \\
\hline Failed to pay employees & $\begin{array}{l}\text { ECs must engage the services of professional accountants to manage cash flow and avoid engaging labour if there is no } \\
\text { money to pay. }\end{array}$ \\
\hline Delays on site due to main contractor problems & $\begin{array}{l}\text { A thorough assessment with the main contractor should be done to ensure enough work is ready for execution before } \\
\text { labour and machinery is brought to site. }\end{array}$ \\
\hline $\begin{array}{l}\text { No proper records kept to track on business } \\
\text { transaction }\end{array}$ & ECs must engage professional services such as business administrators to keep records. \\
\hline Stopped working waiting for payment & Clients should guarantee adequate funding before commencement of the project. \\
\hline Paid employees for medicals, first aid training & ECs should include all costs when completing bills of quantities and ensure such costs are recovered. \\
\hline
\end{tabular}




\section{Reliability and Validity}

Validity was ensured through member checks. The researcher employed the services of a knowledgeable and experienced outsider to review the field notes and interview scripts and data analysis and findings. This enabled the independent reviewer to check if the explanations given by the respondents were fair, honest and balanced from the viewpoint of respondents who encountered such critical financial incidents. This strategy ensured that the critical incidents were carefully selected. Reliability refers to how consistently a technique measures concepts so that other researchers get the same results when the same process is repeated (Yin, 2009). This study relied on the knowledge and experience of the respondents as all were experts as builders, steel fixers, carpenters and general contractors. This ensured that the information was stable and could be acquired again the same way over a period of time accurately. Also, validity and reliability were boosted by piloting the instrument. Before administering the questionnaire to the participants in the study, the researcher tested it to two knowledgeable respondents who brought to light weaknesses of the instrument and the survey techniques.

\section{Conclusion and Recommendations}

An analysis on frequency of occurrence has indicated that the financial incidents with severe impact on ECs' performance are late payment of claims by main contractor, ECs' inability to properly manage cash flow, poor budgetary planning and cash flow, corruption and bribery, poor financial decision making, lack of collateral and assets required by the bank. The incidents have the most impact on ECs' business performance and ways of resolving the incidents have been suggested (table 3 above). Based on the inputs from the respondents, the recommendations are:

- South African government must introduce a policy that enforces the right of ECs to receive payments irrespective of whether the main contractor has been paid.

- Respondents were of the view that the formation of a sector bank would support ECs' business strategies and access to finance at reasonable rates.

- ECs must charge competitive prices that would enable them to realize high profit margins and sustain growth.

- Executives of ECs' require developing financial management skills that would enable them to understand and manage financial requirements needed by investors and other stakeholders.

- Respondents were of the opinion that clients must ensure adequate funding of projects before execution to avoid unnecessary time overrun.

\subsection{Implications for the Performance of ECs}

This study has shown that ECs should utilise the CIT technique as a practical technique for identifying the financial challenges in the construction industry. The technique has successfully revealed the critical financial incidents that affect the performance of ECs in the 
province. However, currently there is no tool that has been developed in South Africa that relevant stakeholders to the construction industry could utilise as a practical tool for identifying the financial challenges. The guide that was developed for this study was limited to Gauteng province and it needs to be validated to enable all construction stakeholders in South Africa utilise it. The implication of this study is that CIT could be utilised as a tool that can resolve financial problems to a certain extent.

\subsection{The Gap and Contribution of the Study}

This study has closed the existing gap and contributed to new knowledge in two ways:

- Although the CIT research method has been previously employed in other disciplines such as tourism and hospitality, fewer studies if any have employed this technique to gather information associated with financial challenges within the South African construction industry. This study has revisited the CIT and applied it within a new context, namely construction industry, and the Gauteng Province in South Africa. Despite being the oldest method of research, the use of CIT in this research has closed the existing gap by adding the technique as a valid and relevant research method that should be utilised in the construction industry. There has been general omission in literature of how incidents could be identified and analysed for strategic decision making in construction organisations in general.

- Using the CIT method, 28 financial critical incidents impacting on emerging contractors' performance were identified. Based on the identified incidents, ways of resolving the incidents were explored and presented for the benefit of South African ECs' especially in Gauteng province. This aspect is an important contribution of this study as the contractors are eager to know the ways of resolving the incidents encountered.

\subsection{Limitations and Future Research}

- The main limitation was the sample size. The sample size was limited to 12 respondents and this could be prone to researcher bias. Therefore, it is difficult to generalise the findings within the entire South African construction industry.

- The study was also limited to the perceptions of executives of ECs in Gauteng, and could not capture the perceptions of other players, such as the main contractors, clients and consultants who have perceptions about ECs performance.

- In order to generalise the findings of this study, further research needs to be done, employing a questionnaire survey based on the findings from the interviewees and perform statistical analysis to make wide claims and conclusions.

\section{Reference}

Baloyi, L., \& Bekker, M. (2011). Causes of construction cost and time overruns: The 2010 FIFA World Cup stadia in SA. Acta Structilia, 18(1), 51-67.

Bitner, M. J., Booms, B. H., \& Mohr, L. A. (1994). Critical Service Encounters: The Employee's Viewpoint. Journal of Marketing, 58(4), 95-106. http://dx.doi.org/10.2307/1251919 
Booyens, I. (2011). Are Small, Medium and Micro sized enterprises engines of innovation? The reality in SA. Science and Public Policy, 38(1), 67-78. http://dx.doi.org/10.1093/scipol/38.1.67

Buys, F., \& Daluxolo, L. (2012). The potential of built environment professionals' contribution towards emerging contractor development. Acta Structilia, 19(2), 74-89.

Construction Industry Development Board (CIDB). (2010). National Register of Contractors, Pretoria: CIDB.

Construction Industry Development Board (CIDB). (2013). Subcontracting in the SA Construction Industry; Opportunities for Development, Pretoria: CIDB.

Emuze, F. A. (2011). Performance improvement in SA construction. PhD Thesis, Nelson Port Elizabeth: Mandela Metropolitan University.

Greyling, E. (2012). Opportunities for Employment Creation through SME Development in the construction sector, Free State. International Labour Organisation.

Holloway, I., \& Wheeler, S. (2002). Qualitative Research in Nursing (2nd ed.). Oxford: Blackwell.

Keaveney, S. M. (1995). Customer Switching Behavior in Service Industries: An Exploratory Study. Journal of Marketing, 59(April), 71-82. http://dx.doi.org/10.2307/1252074

Marrelli, A. F. (2005). The Performance Technologist's toolbox: Critical Incidents. http://dx.doi.org/10.1002/pfi.4140441009

Odeyinka, H. A., \& Kaka, A. (2005). An evaluation of contractors' satisfaction with payment terms influencing construction cash flow. Journal of Financial Management of Property and Construction, 10(3), 171-180. http://dx.doi.org/10.1108/13664380580001074

Ofori, G. (2009). Construction SMME development. Isiza. Issue 6. [Online] Available: http://www.isiza.co.za/features/cidb/982388.htm

Parahoo, K. (1997). Nursing Research: Principles, process and issues. London: Macmillan. http://dx.doi.org/10.1007/978-1-349-14559-1

Patton, M. (2002). Qualitative research and evaluation methods (3rd ed.). Thousand Oaks, CA: Sage Publications.

Serenko, S., \& Stach, A. (2009). The Impact of Expectation Disconfirmation on Customer Loyalty and Recommendation Behavior: Investigating online Travel and Tourism Services. Journal of Information Technology Management, 20(3), 26-41.

Twala, W. D., \& Mvubu, M. (2009). Problems facing small and medium size contractors in Swaziland. Journal Service Science and Management, 2, 353-361. http://dx.doi.org/10.4236/jssm.2009.24042

Yin, R. K. (2009). Case Study Research, Design and Methods: Applied Social Research Methods Series (4th ed.). London: Sage. 


\section{Copyright Disclaimer}

Copyright for this article is retained by the author(s), with first publication rights granted to the journal.

This is an open-access article distributed under the terms and conditions of the Creative Commons Attribution license (http://creativecommons.org/licenses/by/3.0/). 